Araştırma Makalesi / Research Article

\title{
THE VALIDITY OF THE PURCHASING POWER PARITY HYPOTHESIS IN OECD COUNTRIES: EVIDENCE FROM THE FOURIER TEST
}

\section{Süreyya İMRE 1}

\begin{abstract}
According to purchasing power parity (PPP), the nominal exchange rate between the two currencies should be equal to the ratio of the total price levels between the two countries. In other words, it is a simple theory that argues that countries' currencies will have the same purchasing value. In this study, 25 OECD countries is aimed to test the validity of the purchasing power parity hypothesis. The validity of the hypothesis was tested with the monthly data of 1980-Q1 2018-Q12 and Fourier KPSS unit root tests. As a result of the analysis, the validity of the purchasing power parity hypothesis was provided in Brazil, France, Italy, Sweden, Iceland, Ireland, Spain; It has been determined that the purchasing power parity hypothesis is not valid in the countries of Australia, Austria, Belgium, Canada, Germany, Japan, Malaysia, Mexico, Switzerland, USA, Chile, Colombia, Finland, Luxembourg, Netherlands, New Zealand, Norway, Portugal.
\end{abstract}

Keywords: OECD Countries, Purchasing Power Parity, Real Exchange Rate, Fourier KPSS Unit Root Tests

\section{OECD ÜLKELERİNDE SATIN ALMA GÜCÜ PARİTESİ HIPOTEZININ GEÇERLILIĞİ: FOURIER TESTINDEN KANITLAR}

$\ddot{O} z$

Satın alma gücü paritesi (PPP)'ne göre iki para birimi arasındaki nominal döviz kurunun iki ülke arasındaki toplam fiyat seviyelerinin oranına eşit olması gerekir. Diğer bir deyişle ülkelerin para biriminin aynı satın alma değerine sahip olacağını savunan basit bir teoridir. Bu çalışmada da 25 OECD ülkesinde satın alma gücü paritesi hipotezinin geçerliliğini sinamak amaçlanmıştır. 1980-Q1 2018-Q12 dönemine ait aylık veriler ile Fourier KPSS birim kök testleri ile hipotezin geçerliliği sınanmıştır. Analiz sonucunda Brezilya, Fransa, Italya, İsveç, İzlanda, İlanda, İspanya ülkelerinde satın alma gücü paritesi hipotezinin geçerliliğinin sağlandiğı; Avustralya, Avusturya, Belçika, Kanada, Almanya, Japonya, Malezya, Meksika, İsviçre, ABD, Şili, Kolombiya, Finlandiya, Luxemburg, Hollanda, Yeni Zelanda, Norveç ve Portekiz ülkelerinde ise satın alma gücü paritesi hipotezinin geçerli olmadığı tespit edilmiştir.

Anahtar Kelimeler: OECD Ülkeleri, Satın Alma Gücü Paritesi, Reel Döviz Kuru, Fourier KPSS Birim Kök Testleri

\footnotetext{
${ }^{1}$ Res. Assist., Istanbul Gelisim University, Faculty of Economics, Administrative and Social Sciences, Department of Management Information Systems, simre@gelisim.edu.tr, orcid.org/0000-0001-8904-6635
} 


\section{Introduction}

Purchasing power parity emerged among industrialized countries after massive inflation in the years after World War I. The idea that purchasing power parity can be valid is related to the Law of One Price. The Law of One Price is a law that recognizes that the price of a commodity that is subject to international trade should be the same all over the world (Taylor and Taylor, 2004). According to this law, a PPP exchange rate between the respective countries is considered to be valid if the goods are included in each country's basket with the same weight used to establish the total price level.

The existence of purchasing power parity (PPP) has been an important debate among economists for many years. With the PPP theory, the exchange rate is expected to adapt over time to the inflation differences between the two countries (Anoruo, Braha and Ahmad, 2002). Whether the two countries are financially compatible is an indicator of the validity of the PPP. PPP is used both to measure the long-term equilibrium value of the currency and to evaluate the efficiency of the foreign exchange market. Therefore, it is extremely important to measure the validity of the PPP.

Since the purchasing power parity is used for the long-term value of the exchange rates, it determines whether the exchange rates are permanent, therefore, the tendency to return to the average in the long run is related to the validity of the purchasing power parity hypothesis when determining the exchange rates between countries (Anoruo, Braha and Ahmad, 20029. In countries where purchasing power parity is valid, income differences can be measured and welfare levels can be compared.

It is possible to test the validity of the PPP in absolute and relative terms.

Absolute purchasing power parity means that the equilibrium exchange rate between currencies is equal to the ratio between the prices of different countries (Frenkel, 1978). It depends on price indices consisting of weighted averages of more than one commodity. The representation of absolute purchasing power parity is as follows:

$$
\mathrm{P}_{\mathrm{t}}=\mathrm{S}_{\mathrm{t}} \times P_{t}^{*} \text { or } \mathrm{S}_{\mathrm{t}}=\mathrm{P}_{\mathrm{t}} / P_{t}^{*}
$$

Here, $\mathrm{S}_{\mathrm{t}}$ denotes the nominal exchange rate, $\mathrm{P}_{\mathrm{t}}$ and $P_{t}^{*}$ are the domestic and foreign price index, which measures the weighted average of a particular basket of goods, respectively (Copeland, 2005).

Relative purchasing power parity argues that the percentage change in the exchange rate will equal the percentage change in the price level of countries (Gandolfo, 2002). It deals with the changes that will occur in the exchange rates since a certain starting year. The representation of relative purchasing power parity is as follows:

$$
\Delta \mathrm{S}_{\mathrm{t}}=\frac{\left(\Delta P_{\left.t-\Delta P_{t}^{*}\right)}\right.}{\left(1+\Delta P_{t}^{*}\right)}
$$


Here, $\Delta \mathrm{S}_{\mathrm{t}}$ is the annual percentage change in the nominal exchange rate, and $\mathrm{P}_{\mathrm{t}}$ and $P_{t}^{*}$ are the annual percentage changes in domestic and international prices (Mike, 2018).

It is stated that the absolute purchasing power parity and the real exchange rate are a fixed number. However, the absolute purchasing power parity condition is not fulfilled for many reasons (Gerek and Karabacak, 2017).

In real life, it is seen that international price indices vary and different weights are given to goods. Since the weights given to the goods in each country are different, it is clear that the increase and decrease in the price of the goods with the higher weight in the price indexes of the countries will have asymmetric effects on the price indices of the countries. For this reason, many studies are based on relative purchasing power parity, which does not require identical baskets of goods or price indices with the same weight.

Since the PPP hypothesis forms the basis of open economy macro models, its validity is of great economic importance (Sarno and Taylor, 2002). PPP is also an important criterion in terms of foreign competition since it can evaluate the foreign competitiveness of countries under the real exchange rate criterion. The fact that PPP is closely related to exchange rate parity and exchange rate policies, is an effective measurement tool in international comparisons and is used in policy applications has made it extremely important to test the validity of this theory (Şener et al., 2015).

Studies on purchasing power parity are important for both empirical researchers and policy makers. It is very important in determining whether the PPP exchange rate is low, taking appropriate policy decisions, adjusting exchange rate parities, and comparing whether there is a difference between the domestic price and the foreign price (Sarno and Taylor, 2002). The validity of the PPP is evaluated as a criterion in comparisons of the level of development, the reliability of the economic decisions taken and the estimation of real exchange rates (Güriş et al., 2016).

The purchasing power parity hypothesis is important to economic policy authorities for two main reasons. These; It is to analyze whether the exchange rate is overvalued in countries where domestic inflation is higher than foreign inflation, to reveal the basic structure of how exchange rates are determined, and to accept the validity of the purchasing power parity hypothesis as the main assumption when determining the exchange rate within the framework of the relevant model (Karoglou and Morley, 2012).

According to Chortareas and Kapetanios (2009), the validity of PPP is an important piece of information for analyzing the effects of devaluation. PPP is also a necessary condition for maintaining the integrity of the market and equalizing its marginal utility. In the literature, cointegration tests and unit root tests are used to evaluate the validity of PPP (Chortareas and Kapetanios, 2009). The most common way to test the validity of PPP is unit root analysis. If the unit root can be rejected, deviations from purchasing power parity are said to be temporary (Lopez and Papell, 2002). 
In this study, the validity of PPP was tested with Fourier unit root tests, which are considered among the current econometric techniques and are not yet very common in the literature. In addition, the purchasing power parity in this study differs from many studies in the literature in terms of both the number of countries and the length of time dimension. For this purpose, the study is discussed in four parts. In the first part, the introduction part, the theory of PPP is explained, and in the second part, a literature review is given. In the third part, the data set and econometric methodology are explained and in the fourth part, the findings are interpreted. In the last part, an evaluation was made.

\section{Literature Review}

The theory of validity of purchasing power parity has a very intensive study area. This test is done with unit root tests and cointegration tests. While the first studies used linear tests, recent studies have focused on nonlinear tests. In addition, due to the lack of data and the lack of development of econometric methods, it is observed that the first period studies were generally carried out in line with short-term analyzes. The findings obtained in this period mostly indicate that the theory is not valid. However, it can be seen that the findings on the validity of the theory have increased with the development of tests that will allow for the ease of data acquisition and long-term analysis. This situation contributes to the formation of a very dense literature on the theory today.

Telatar and Kazdağlı (1995) using monthly data for the period 1980:101993:10, they investigated the validity of purchasing power parity for Turkey, France, Germany, England and the United States with PP (1988) and ADF (1979, 1981) unit root tests. It was observed that the long-term PPP hypothesis was not valid in the countries studied.

Lee (1999) used the generalized error correction model to test the validity of purchasing power parity in 13 emerging and industrialized Asia Pacific economies. It concluded that for the countries included in the analysis, the PPP is valid in the long run.

Erlat (2003) used the data for the period 1984.01-2000.09 to investigate the persistence of two exchange rates in Turkey, the German DM and the US Dollar. Unit root tests and ARFIMA models were used in the analysis. According to the results obtained, almost all series were found to be stationary. Thus, the validity of the "half" purchasing power parity hypothesis was accepted.

Alba and Papell (2007) examined the validity of the PPP hypothesis in a total of 84 developed and developing countries for the period 1976-2002 with Panel unit root tests. As a result of the analysis, it has been determined that the PPP hypothesis is valid in Europe and Latin America, but not in Africa and Asia.

Abumustafa and Feridun (2010) The validity of the purchasing power parity hypothesis in Egypt, Jordan and Turkey between 1976:01-2000:01 was examined with (ADF), (PP) and (KPSS) unit root tests. While the ADF and PP tests showed that PPP failed in all three countries, the KPSS test only showed that the SGP was successful for all three countries in the trend. This situation revealed that the PPP 
results will vary according to the preferred empirical method, not according to the countries.

Bozoklu and Y1lanc1 (2010) investigated the validity of purchasing power parity for seven developing countries with data from January 1995 to December 2009. At the end of the analysis, they concluded that PPP is valid only in China and Mexico, while PPP is not valid in the remaining five countries, Brazil, Indonesia, India, Russia and Turkey.

Liu, Su and Zhu (2011) in this study, it is aimed to determine whether the real exchange rate is stable for 7 European countries with the nonlinear threshold unit root test, Caner and Hansen (2001). As a result of the analysis, it has been determined that the PPP is valid for Slovakia, Romania and Bulgaria.

Holmes et al. (2012) the validity of the PPP hypothesis in OECD countries with the data for the period 1972-2008 was examined by Hadri and Rao diffraction panel unit root tests. It was concluded that the PPP hypothesis is valid in 26 OECD countries.

Özcan (2012) tested the validity of the PPP hypothesis for the G-7 countries by using data from 1980-2010. According to the PANKPSS test results, PPP was accepted as valid.

Cuestas and Regis (2013) investigated whether the PPP hypothesis in OECD countries is valid for the period 1972:01-2010:01 using linear and nonlinear unit root testing. While it is valid in 11 countries according to empirical results, it is invalid in Turkey.

Haji-Othman and Yahaya (2014) The validity of PPP was tested with DF and ADF unit root tests in Chile, Uruguay, Turkey, Sierra Leone, Suriname, Mexico, Malaysia, Singapore, Netherlands, Switzerland with annual data between 19731996. It is concluded that only Mexico and Sierra Leone support the PPP theory among the five selected high inflation countries, and that there is no cointegration between the exchange rate and PPP in Turkey. It was found that the PPP theory was not supported in any of the selected low-inflation countries. It was also concluded that as a country's inflation rate increases, the PPP may be valid.

He et al. (2014) investigated the validity of PPP with the Fourier Panel SURKSS unit root test using data from December 1994 to February 2010 in their study. According to the results of the Fourier Panel SURKSS test, they stated that PPP is valid in 15 Latin American countries except Honduras.

Jiang et al. (2015) for 34 OECD countries, for the period January 1994August 2013, to verify the validity of PPP through the sharp breaks and smooth shift panel unit root test proposed by Bahmani. They have shown that PPP is valid in $17 \mathrm{OECD}$ countries.

Vasconcelos and Junior (2016) tested the validity of purchasing power parity in Argentina, Brazil, Chile, Colombia, Mexico, Peru and Venezuela with linear and nonlinear unit root tests. At the end of the analysis, it has been determined that purchasing power parity is valid for Mexico, Chile and Peru. 
Ma, Li and Park (2017) tested the validity of the purchasing power parity (PPP) hypothesis for China, Japan, and South Korea using quantile unit root and quantile cointegration methods. When traditional methods are used, the PPP hypothesis is strongly rejected for all three countries. However, the PPP hypothesis is valid for China at the quantitative levels and is valid for Japan at the lower and upper quantitative levels. In addition, the PPP hypothesis for South Korea is valid at all quantitative levels when the consumer price index (CPI) is used as the price variable.

Kaya and Çelik (2018) in order to test the validity of purchasing power parity, the data for the period 2002:10-2017:12 and the dollar rate and the euro rate series are discussed. ARFIMA model was used in the analysis. As a result of the analysis, it was found that both dollar and euro real exchange rates have long memory properties. This showed that the PPP hypothesis is valid for Turkey.

Bozgeyik and Aydin (2019) analyzed monthly data covering the period 1994.01-2019.05 in order to examine whether PPP is valid in developing countries in this study. According to the results of the Fourier ADF (FADF-SB) test developed by Furuoka (2017), it has been determined that the PPP theory is valid for 16 developing countries, including Turkey.

Wang et al. (2019), evaluated whether purchasing power parity (PPP) is valid in China by examining the dynamic link between the nominal exchange rate (NER) and the relative consumer price (RCP) and found that PPP is not valid in China. The sliding window causality method was applied for the dynamic causality connection and as a result, they observed that the nominal exchange rate had both positive and negative effects on the relative consumer price in some subperiods.

\section{Dataset and Econometric Methodology}

Ethics committee approval and/or legal/special permission were not required in this study, and research and publication ethics were complied with.

In this study, in 25 OECD countries (Brazil, France, Italy, Sweden, Iceland, Ireland, Spain Australia, Austria, Belgium, Canada, Germany, Japan, Malaysia, Mexico, Switzerland, USA, Chile, Colombia, Finland, Luxembourg, Netherlands, New Zealand, Norway, Portugal) Becker Enders Lee (2006) Fourier Stationarity Test was used to test the validity of the purchasing power parity hypothesis. Monthly data for the period 1980-Q1 2018-Q12 were compiled from International Financial Statistics (IFS). Analyzes were carried out by taking the logarithm of the real exchange rate used to represent purchasing power parity. Eviews10 and WinRATS programs were used in the analysis.

Becker, Enders, and Lee (2006) developed a new stationarity test based on the Kwiatkowski et al (1992) stationarity test using the Fourier function. In this stationarity test, the main reason for using the Fourier function is that it can model the motion of unknown functions, and in this test not only sudden changes, but also slow changes can be detected, and the location, number and shape of the structural break(s) are not important. 
In order to calculate the test statistics required for the application of the test by defining the stationarity to the null hypothesis, the following models are estimated by the Least Squares (OLS) method in the first stage, and the residuals of the models are obtained. In the second step, the unit root is applied to these residues:

$$
\begin{aligned}
& y_{t}=\alpha+\gamma_{1} \sin \left(\frac{2 \pi k t}{T}\right)+\gamma_{2} \cos \left(\frac{2 \pi k t}{T}\right)+\varepsilon_{t} \\
& y_{t}=\alpha+\beta t+\gamma_{1} \sin \left(\frac{2 \pi k t}{T}\right)+\gamma_{2} \cos \left(\frac{2 \pi k t}{T}\right)+\varepsilon_{t}
\end{aligned}
$$

The first model considers the constant term, the second model considers the constant term and trend structure. $\mathrm{T}$ is the sample size, $\mathrm{k}$ is the number of frequencies, and $t$ is the trend term. The point to be considered when estimating these models is to correctly determine the number of frequencies expressed as $\mathrm{k}$. Because the test statistic, that is, the distribution, changes according to the $\mathrm{k}$ value. The appropriate frequency number is the frequency number that makes the residual sum of squares of the models shown above the smallest.

To test the main hypothesis showing stationarity, residual values are obtained from the above equations. The test statistic is found with the following equation:

$$
\tau_{\mu}(k) \text { veya } \tau_{\tau}(k)=\frac{1}{T^{2}} \frac{\sum_{t=1}^{T} S_{t}(k)^{2}}{\tilde{\sigma}^{2}}
$$

Although the test statistics are obtained as shown, in this test, it can be decided whether the test statistic shown above can be used or not by placing a zero constraint on the parameters in front of the trigonometric variables in the models. If the stationarity hypothesis is not rejected, if the series is found to be stationary, the significance of the Fourier terms should be tested. Accordingly, the $\mathrm{F}$ test is used only for the series whose stationarity hypothesis is not rejected (Becker, Enders and Lee, 2006).

If there is no nonlinear trend in the data generation process, the current standard KPSS test gives stronger results than the Fourier KPSS test. Therefore, the main hypothesis expressing the absence of nonlinear trend is calculated with the following F-test statistic:

$$
\begin{aligned}
& H_{0}: \gamma_{1}=\gamma_{2}=0 \\
& H_{1}: \gamma_{1} \neq \gamma_{2} \neq 0
\end{aligned} \quad F(k)=\left(\frac{S S R_{0}-S S R_{1}(k) / 2}{S S R_{1}(k) /(T-k)}\right)
$$

Here, $\mathrm{SSR}_{0}$ is the residual sum of squares without trigonometric terms, $\mathrm{SSR}_{1}(\mathrm{k})$ is the residual sum of squares obtained from fixed or constant-trend models, and $\mathrm{k}$ is the number of explanatory variables. In case the null hypothesis is rejected; 
$\tau_{\mu}(\mathrm{k})$ veya $\tau_{\tau}(\mathrm{k})$

test statistics can be used. Otherwise, if the null hypothesis cannot be rejected, the test statistic gives the classical KPSS test statistic. For this case, Becker, Enders and Lee obtained critical values.

\section{Findings}

In the study, before proceeding to the unit root tests, it was desired to investigate whether the series included a trend, graphics were created for the countries included in the study in this direction, and the results are presented in Chart1.

Chart 1: Movement of Purchasing Power Parity Over Time
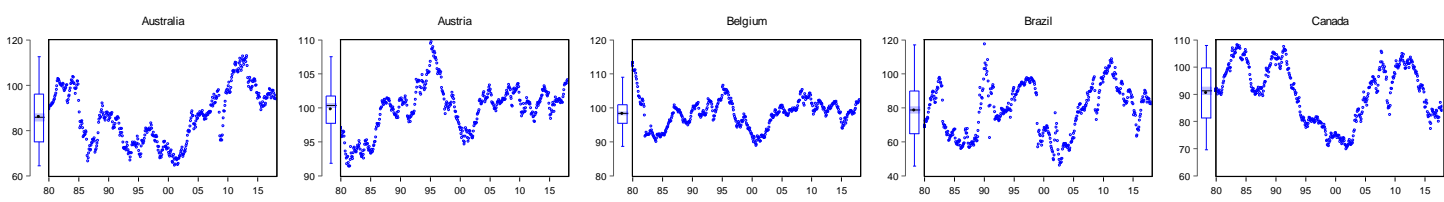

Chile

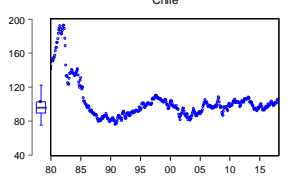

Iceland

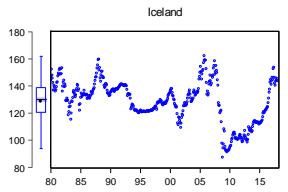

Malassi

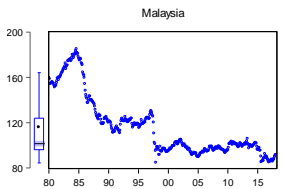

Partugal

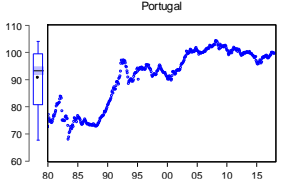

Colombia

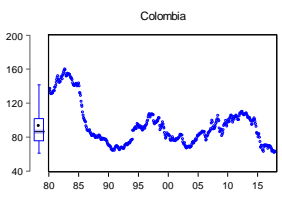

Ireland

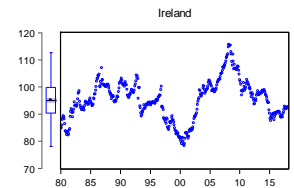

Mexico

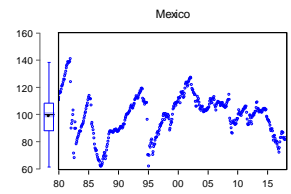

Spair

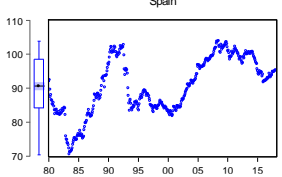

Finland

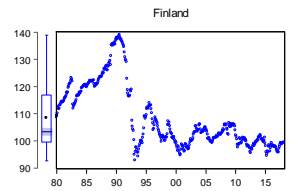

laaly

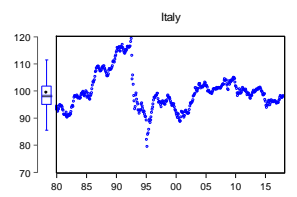

Netherands

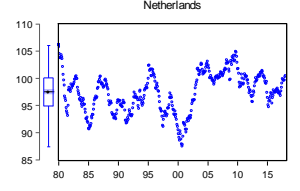

Sweden

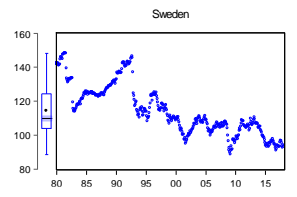

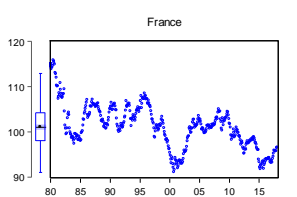

Japan

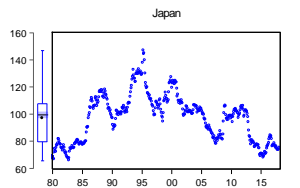

New Zealand

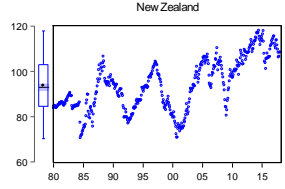

Switerand

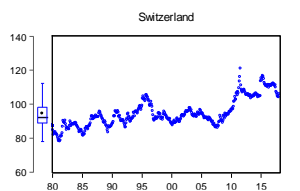

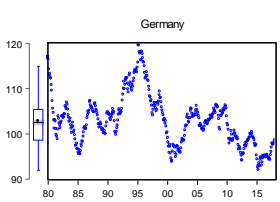

wermbourg

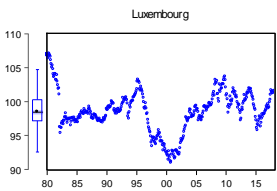

Norway

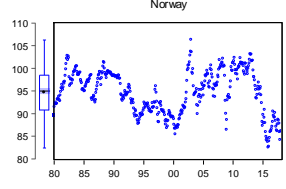

United States

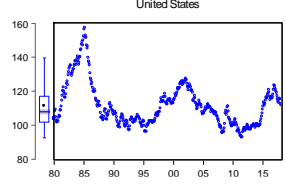

When the time series graphs are examined, it can be said that there are structural breaks in purchasing power parity in all countries over time and that the variables contain trends. Since it is observed that the series contain a trend, the results are reported using the fixed and trended structure of the Fourier KPSS unit root test.

According to the results of the Fourier KPSS test, the significance of the trigonometric terms in the series found to be stationary is tested with the F test. Accordingly, the validity of the Fourier KPSS or classical KPSS unit root test is indicated. If the trigonometric terms are not significant, classical KPSS unit root 
test results should be reported. For this purpose, Fourier KPSS $t$ statistical values and $\mathrm{F}$ test statistical values are reported together in Table 1.

Table 1: Fourier KPSS Stationarity Test Results for PPP

\begin{tabular}{|c|c|c|c|c|}
\hline \multirow{2}{*}{ Countries } & \multirow{2}{*}{$\begin{array}{l}\text { Frequency } \\
\text { (k) }\end{array}$} & \multirow{2}{*}{ Min KKT } & FKPSS & FKPSS \\
\hline & & & t-statistic & F-statistic \\
\hline Australia & 1 & 21698.73 & 0.06407 & 427.26238 \\
\hline Austria & 1 & 2778.998 & 0.09339 & 130.75228 \\
\hline Belgium & 2 & 6202.23 & 0.13793 & 70.98696 \\
\hline Brazil & 2 & 59291 & 0.12463 & 131.06583 \\
\hline Canada & 2 & 28915.29 & 0.5885 & 142.25055 \\
\hline France & 3 & 4888.867 & 0.07339 & 64.94122 \\
\hline Germany & 3 & 8380.464 & 0.37326 & 85.1764 \\
\hline Italy & 2 & 9346.138 & 0.11311 & 268.75349 \\
\hline Japan & 1 & 48584.91 & 0.06215 & 402.4479 \\
\hline Malaysia & 1 & 41248.03 & 0.06653 & 251.5974 \\
\hline Mexico & 1 & 71839.02 & 0.05813 & 107.78423 \\
\hline Sweden & 2 & 20891.8 & 0.05994 & 87.97073 \\
\hline Switzerland & 1 & 8402.27 & 0.0672 & 129.1844 \\
\hline ABD & 2 & 28912.19 & 0.2005 & 255.1261 \\
\hline Chile & 1 & 91793.81 & 0.16591 & 249.66745 \\
\hline Colombia & 1 & 96290.25 & 0.11836 & 275.87551 \\
\hline Finland & 2 & 19844.89 & 0.20341 & 110.19567 \\
\hline Iceland & 3 & 57588.53 & 0.07563 & 113.90698 \\
\hline Ireland & 2 & 7119.589 & 0.10857 & 517.90289 \\
\hline Luxembourg & 3 & 3071.983 & 0.37865 & 82.16971 \\
\hline Netherlands & 3 & 4185.993 & 0.18623 & 66.8846 \\
\hline New Zealand & 5 & 20998.88 & 0.40064 & 119.54352 \\
\hline Norway & 2 & 6097.074 & 0.17953 & 137.85424 \\
\hline Portugal & 1 & 5514.986 & 0.10474 & 227.77483 \\
\hline Spain & 2 & 8237.8 & 0.09829 & 284.37863 \\
\hline
\end{tabular}

In the table, $\mathrm{k}$ represents the optimal frequency value giving the minimum residual sum of squares. Appropriate critical values are found in Becker Enders Lee (2006). Accordingly, the t statistic critical values for Becker Enders Lee fixed and trended structure are; 
For $\mathrm{k}=1$ and $\mathrm{T}=458$, it is $0.0716,0.0546,0.0471$ for $1 \%, 5 \%$ and $10 \%$, respectively.

For $\mathrm{k}=2$ and $\mathrm{T}=458$, it is $0.2022,0.1321,0.1034$ for $1 \%, 5 \%$ and $10 \%$, respectively.

For $\mathrm{k}=3$ and $\mathrm{T}=458$, it is $0.2103,0.1423,0.1141$ for $1 \%, 5 \%$ and $10 \%$, respectively.

For $\mathrm{k}=5$ and $\mathrm{T}=458$, it is $0.2177,0.1484,0.1201$ for $1 \%, 5 \%$ and $10 \%$, respectively.

In addition, the critical values of $\mathrm{F}$ statistics for Becker Enders Lee constant and trend structure are $6.873,4.972$ and 4.162 for $\mathrm{T}=100$ for $1 \%, 5 \%$ and $10 \%$, respectively. For $\mathrm{T}=500$, it is $6.315,4.669$ and 3.928 for $1 \%, 5 \%$ and $10 \%$, respectively.

The hypotheses for the Fourier KPSS in Becker Enders Lee (2006) article are as follows:

\section{$\mathrm{H}_{0}$ : Stationary \\ $\mathrm{H}_{1}$ : Unit Root}

When the Fourier KPSS t statistical values and the critical values in the Becker Enders Lee (2006) article were compared, it was determined that the null hypothesis could not be rejected and the real exchange rate was stationary in Brazil, France, Italy, Sweden, Iceland, Ireland, Spain. In other words, it has been determined that the validity of the purchasing power parity hypothesis is provided in these countries. On the other hand, it has been found that the purchasing power parity hypothesis is not valid in the countries of Australia, Austria, Belgium, Canada, Germany, Japan, Malaysia, Mexico, Switzerland, USA, Chile, Colombia, Finland, Luxembourg, Netherlands, New Zealand, Norway, Portugal.

F test results should be reported for the series found to be stationary according to the Fourier KPSS test results. It should be decided which Fourier KPSS or standard KPSS test will be used. The hypotheses of the F test are shown as follows:

$$
\begin{aligned}
& H_{0}: \gamma_{1}=\gamma_{2}=0 \\
& H_{1}: \gamma_{1} \neq \gamma_{2} \neq 0
\end{aligned}
$$

Here, the null hypothesis defends the standard KPSS test, and the alternative hypothesis defends the validity of the Fourier KPSS test.

Since the calculated test statistics are larger than the table value, the null hypothesis is rejected and the Fourier KPSS unit root test should be used. Accordingly, the results of the Fourier KPSS unit root test should be trusted.

Finally, the graphs were drawn to determine whether the real exchange rate, which represents the purchasing power parity, is compatible with the Fourier functions, and the results are shown in Graph 2. 
Chart 2. Modelling of Purchasing Power Parity with Fourier Terms

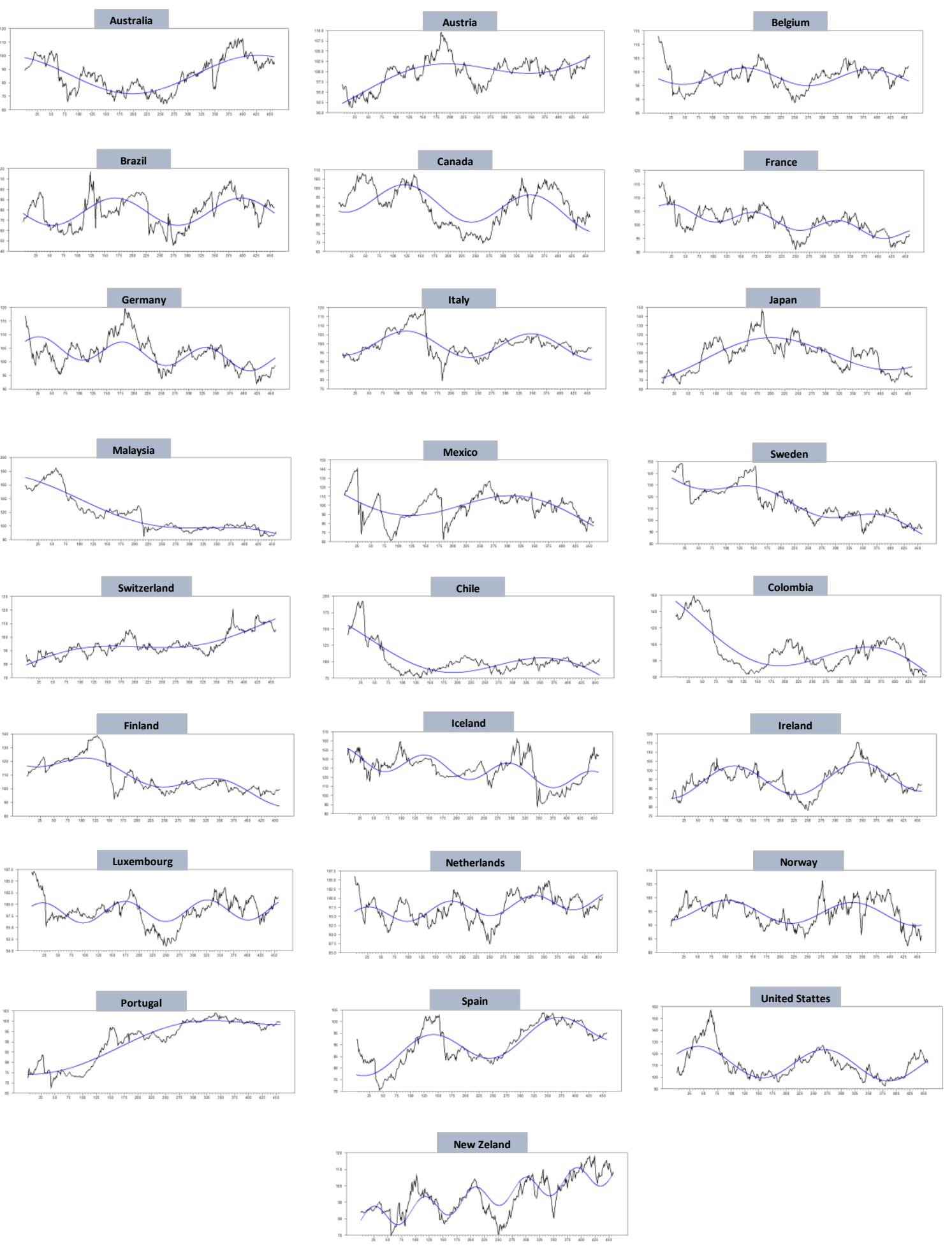


When the graphs of all the countries subject to the analysis are examined, it is seen that the Fourier functions are compatible with the real exchange rate variable, the Fourier estimates are reasonable and they catch the long oscillations in the series.

\section{Conclusion}

PPP is important for exchange rate forecasts. Therefore, PPP is one of the oldest and most controversial doctrines of international finance. One of the reasons is that policy makers, researchers, businesses and consumers want to compare incomes and expenditures when prices change or differ. Comparing incomes and measuring the change in incomes is one of the main tools to analyze the success of economic policies and especially to question development.

The purchasing power parity theory, which began in the 1970s, has been the crux of a lively debate. In most of the theoretical studies discussed in this period, it has been suggested that the relative changes in the price levels of exchange rates can only be related to deviations that may be minimal or momentary. In recent years, more realistic results have been obtained by testing the purchasing power parity hypothesis, especially as nonlinear models have been included in theory and empirical studies.

The 25 OECD Countries covered in this study are Brazil, France, Italy, Sweden, Iceland, Ireland, Spain Australia, Austria, Belgium, Canada, Germany, Japan, Malaysia, Mexico, Switzerland, USA, Chile, Colombia, Finland, Luxembourg, Netherlands. The validity of the purchasing power parity hypothesis was tested in New Zealand, Norway, Portugal. The logarithm of the real exchange rate used to represent the purchasing power parity is included in the analysis. Before starting the unit root test, real exchange rate graphs were obtained on the basis of countries. As can be seen from these graphs, it is understood that the real exchange rate contains trend and structural breaks. In the Fourier KPSS test, not only sudden changes, but also slow changes can be detected and the location, number and shape of the structural break(s) are not important. For this reason, it was decided to use the Fourier KPSS unit root test, which is a more advanced technique, for the validity of the purchasing power parity hypothesis.

As a result of the analysis, it was determined that the purchasing power parity hypothesis was met in Brazil, France, Italy, Sweden, Iceland, Ireland, Spain.

It has been determined that most of the economic shocks in these countries do not cause permanent shocks on the real (effective) exchange rate series, and they return to the averages of the series in the long run. For this reason, the economic policy executors of these countries will be able to determine their foreign trade strategies based on PPP, decide on the optimum level of the exchange rate and implement monetary policies in a way that preserves the value of the national currency.

On the other hand, it has been found that the purchasing power parity hypothesis is not valid in the countries of Australia, Austria, Belgium, Canada, Germany, Japan, Malaysia, Mexico, Switzerland, USA, Chile, Colombia, Finland, Luxembourg, Netherlands, New Zealand, Norway, Portugal. Thus, it proves that 
the series are not stationary in these countries, in other words, they do not tend to return to the mean, and therefore the effects of shocks on the series are permanent. This is an indication that real exchange rates are incorrectly balanced. According to the results of this study; It can be stated that the arrangements made by considering the PPP hypothesis in the evaluations made while determining the exchange rate rates may not yield healthy results. On the other hand, PPP in international comparisons of national income and living standards. It can be said that using it will lead to unreliable results.

Statement of Support and Appreciation: No external support has been received during the conduct of this study.

Researchers' Contribution Rate Statement: The entire study has been prepared only by the responsible author.

Conflict of Interest Statement: We do not have any conflict of interest declaration as the authors of the study.

Research and Publication Ethics Statement: All the rules stated in the "Higher Education Institutions Scientific Research and Publication Ethics Directive" were strictly considered at every stage of this research. None of the actions specified under the heading "Actions Against Scientific Research and Publication Ethics" of the directive has not been carried out. During the writing process of this study, the citations were made in accordance with the ethical rules and a bibliography was created. The study was subjected to plagiarism control.

\section{References}

Abumustafa, N. I., and Feridun, M. (2010). Explaining The Long-Term Real Equilibrium Exchange Rates Through Purchasing Power Parity: An Emprical Investigation On Egypt, Jordan And Turkey. African Journal of Business Management, 4(7), 1260-1265.

Alba, J. D., and Papell, D. H. (2007). Purchasing Power Parity and Country Characteristics: Evidence from the Panel. Journal of Development Economics, 83(1), 240-251.

Anoruo, E., Braha, H., and Ahmad, Y. (2002). Purchasing Power Parity: Evidence From Developing Countries. International Advances in Economic Research, 8(2), 85-96.

Becker, R., Enders, W., and Lee, L. (2006). A Stationarity Test in The Presence Of an Unknown Number Of Smooth Breaks. Journal of Time Series Analysis, 27(3), 382-409.

Bergin, P. R., and Feenstra, R. C. (2001). Pricing-to-Market, Staggered Contracts, and Real Exchange Rate Persistence. Journal Of International Economics, $54(29,333-359$.

Bozgeyik, Y., and Aydın, A. (2019). Seçilmiş Gelişmekte Olan Ülkelerde Satın Alma Gücü Paritesinin Geçerliliğine İlişkin Ampirik Bir Çalışma. Uluslararası Toplum Araştırmaları Dergisi, 13(19), 2068-2089. 
Chortareas, G., and Kapetanios, G. (2009). Getting PPP Right: Identifying MeanReverting Real Exchange Rates In Panels. Journal of Banking \& Finance, 33(2), 390-404.

Copeland, L. (2005). Exchange Rates and International. England: Bell\&Bain Limited.

Cuestas, J. C., and Regis, P. J. (2013). Purchasing Power Parity in OECD Countries: Nonlinear Unit Root Tests Revisited. Economic Modelling, 32, 343-346.

Erlat, H. (2003). The Nature of Persistence in Turkish Real Exchange Rates. Emerging Markets Finance \& Trade, 39(2), 70-97.

Frenkel, J. A. (1978). Purchasing Power Parity: Doctrinal Perspective and Evidence from the 1920s. Journal of International Economics, 8(2), 169-191.

Gandolfo, G. (2002). International Finance and Open Economy Macro-Economics. New York: Springer-Verlag.

Gerek, S., and Karabacak, M. (2017). Satın Alma Gücü Paritesi Yaklaşımı İle Türkiye'de Reel Döviz Kuru Yanlış Dengelenmesinin Belirlenmesi:Yapısal Kırılmalı Ve Doğrusal Olmayan Birim Köktestleri İle Bir Analiz. Journal Of Life Economics, 4(11), 1-24.

Güriş, B., Tiraşoğlu, B. Y., and Tiraşoğlu, M. (2016). Türkiye' de Satın alma Gücü Paritesi Geçerli mi?: Doğrusal Olmayan Birim Kök Testleri. Sosyal Bilimler Araştırma Dergisi, 5(4), 30-42.

Haji-Othman, Y., and Yahaya, S. (2014). Purchasing Power Parity: Evidence From Selected High And Low Inflation Countries. International Business Research, 8(1), 50-59.

He, H., Chou, M., and Chang, T. (2014). Purchasing Power Parity for 15 Latin American countries: Panel SURKSS Test with a Fourier Function. Economic Modelling, 36, 37- 43.

Holmes, M., Otero, J., and Panagiotidiis, T. (2012). PPP in OECD Countries: An Analysis of Real Exchange Rate Stationarity, Cross-Sectional Dependency and Structural Breaks. Open Economies Review, 23(5), 767-783.

Huang, C.H., and Yang, C.Y. (2015). European Exchange Rate Regimes And Purchasing Power Parity: An Empirical Study On Eleven Eurozone Countries. International Review of Economics \& Finance, 23, 100-109.

Jiang, C., Bahmani-Oskooee, M., and Chang, T. (2015). Revisiting Purchasing Power Parity in OECD. Applied Economics, 47(40), 4323-4334.

Karoglou, M., and Morley, B. (2012). Purchasing Power Parity And Structural Instability in the US/UK Exchange Rate. Journal of International Financial Markets Institutions and Money, 22(4), 958-978.

Kaya, H., and Çelik, İ. (2018). Türkiye'de Satın Alma Gücü Paritesi Hipotezinin Geçerliliği: Uzun Hafıza Testlerinden Kanıtlar. Mehmet Akif Ersoy Üniversitesi İktisadi ve İdari Bilimler Fakültesi Dergisi, 5(2), 351-365. 
Lee, C. H., and Chou, P. I. (2013). The Behavior Of Real Exchange Rate: Nonlinearity And Breaks. International Review of Economics and Finance, 27, 67-73.

Lee, D. (1999). Purchasing Power Parity and Dynamic Error Correction Evidence from Asia Pacific Economics. International Review of Economics and Finance, 8(2), 199-212.

Liu, Y. S., Su, C. W., and Zhu, M. N. (2011). Purchasing Power Parity With Threshold Effects For Central And Eastern European Countries. Applied Economics Letters, 18(18), 1801-1806.

Lopez, C., and Papell, D. H. (2002). Convergence to Purchasing Power Parity at the Commencement of the Euro. Review of International Economics, 5(1), 118.

Ma, W., Li, H., and Park, S. Y. (2017). Empirical Conditional Quantile Test For Purchasing Power Parity: Evidence From East Asian Countries. International Review of Economics \& Finance, 49, 211-222.

Mike, F. (2018). Gelişen Piyasa Ekonomilerinde Satınalma Gücü Paritesinin Geçerliliğinin Test Edilmesi. Finans Politik \& Ekonomik Yorumlar, 55(637), 7-30.

Özcan, B. (2012). Satın Alma Gücü Paritesi G7 Ülkeleri İçin Geçerli mi? Hacettepe Üniversitesi İktisadi ve İdari Bilimler Fakültesi Dergisi, 30(2), 137-162.

Sarno, L., and Taylor, M. P. (2002). Purchasing Power Parity and the Real Exchange Rate. IMF Staff Papers, 65-105.

Şener, S., Yılanc1, V., and Canpolat, E. (2015). Satin Alma Gücü Paritesi Ve Varyasyonlarinin Türkiye İçin Sinanmasi. Int. Journal of Management Economics and Business, 11(25), 53-63.

Tatoğlu, F. Y. (2009). Reel Efektif Döviz Kurunun Duranliğinin Yapisal Kirilmali Panel Birim Kök Testleri Kullanilarak Sinanmasi. Doğuş Üniversitesi Dergisi, 10(2), 310-323.

Taylor, A. M., and Taylor, M. P. (2004). The Purchasing Power Parity Debate. Journal of Economic Perspectives, 8(4), 135-158.

Telatar, E., and Hasanov, M. (2009). Purchasing Power Parity in Central and East European Countries. Eastern European Economics, 47(5), 25-41.

Telatar, E., and Kazdağl1, H. (1995). Re-Examine The Long-Run Purchasing Power Parity Hypothesis For A High Inflation Country: The Case of Turkey 198093. Applied Economics Letters, 5(1), 51-53 .

Vasconcelos, C. R., and Júnior, L. A. (2016). Validity Of Purchasing Power Parity For Selected Latin American Countries: Linear And Non-Linear Unit Root Tests. EconomiA, 17(1), 114-125.

Wang, K.-H., Su, C.-W., Tao, R., and Xiong, D. P. (2019). Does The Purchasing Power Parity Fit For China? Economic Research, 32(1), 2028-2043. 